ISSN: 2146-3042

DOI: $10.25095 /$ mufad.940857

\title{
TFRS 15 Müşteri Sözleşmelerinden Hasılat Standardına Geçişin BİST 100 Endeksindeki Firmaların Finansal Tablolarına Etkileri*
}

\author{
Korten TEZEL** \\ Derya ÜÇOĞLU***
}

\section{ÖZET}

Hasılatın muhasebeleştirilmesi konusunda yeterli rehberlik sağlayamayan TMS 11 İnşaat Sözleşmeleri ve TMS 18 Hasılat standartlarının yerini 1 Ocak 2018'den itibaren yürürlüğe girmiş olan TFRS 15 Müşteri Sözleşmelerinden Hasılat standardı almıştır. Bu çalışmada beș adım modeli ile hasılatın muhasebeleștirilmesi konusunda yeni bir çerçeve çizmiş olan TFRS 15'e geçişin BIST 100 endeksindeki firmaların finansal tablolarına etkileri incelenmiştir. TFRS 15 'e geçişin etkisini belirlemek için, geçiş yıl olan 2018 yll sonu finansal tablolarına ve dipnotlarına içerik analizi yapılmıştır. TFRS 15 uygulamasına iliş̧kin olarak gerekli finansal verileri (TFRS 15 öncesi ve sonrası) açıklamış olan 16 işletmenin geçişten etkilenen kalemlerindeki yüzdesel değişimler hesaplanmış, söz konusu değişimlerin istatistiksel olarak anlamlı olup olmadığının belirlenmesi için ilişkili (bağımlı) örnekler t testleri yapılmıștır. Araștırma bulgularına göre, TFRS 15'in varlıklar üzerindeki etkilerinin ve karlılık üzerindeki olumlu etkilerinin en belirgin olarak teknoloji ile ulaştırma, haberleşme ve depolama sektörlerinde ve karlılık üzerindeki olumsuz etkilerinin de özkaynak yöntemiyle değerlenen yatırımlar nedeniyle bir holding üzerinde görülmesi söz konusudur. Ancak yeni hasılat standardına geçişin hiçbir finansal tablo kalemi üzerinde istatistiksel olarak önemli bir etkisinin olduğu da tespit edilememiştir. Modeli

Anahtar Kelimeler: TFRS/UFRS 15, Hasılatın Muhasebeleştirilmesi, Müşteri Sözleşmelerinden Hasılat, Beş Adım JEL Sinıflandirması: M40, M41

\section{The Effects of The Transition to TFRS 15 Revenue From Contracts with Customers} Standard on The Financial Statements of The Companies Listed in BIST 100 Index

\section{ABSTRACT}

TAS 11 Construction Contracts and TAS 18 Revenue standards that could not provide sufficient guidance on revenue recognition were replaced by TFRS 15 Revenue from Contracts with Customers standard, which came into effect as of January 1, 2018. In this study, the effects of the transition to TFRS 15, which has created a new framework for the recognition of revenue with the five-step model, on the financial statements of companies in the BIST 100 index have been examined. To determine the impact of the transition to TFRS 15, content analysis was performed on the 2018 year-end financial statements and footnotes. Percentage changes in the affected items of sixteen companies that have disclosed the necessary financial data regarding TFRS 15 implementation (before and after TFRS 15) were calculated, and paired (dependent) samples t-tests were performed to assess whether these changes were statistically significant. According to the research findings, the effects of TFRS 15 on assets and favorable impact on profitability are most evident in the technology, transportation, communication and storage sectors, and an unfavorable profitability effect is identified for a holding company due to its investments accounted for under the equity method. This study could not determine any statistically significant impact on financial statement items regarding the transition to the new revenue standard.

Keywords: TFRS/IFRS 15, Revenue Recognition, Revenue from Contracts with Customers, Five-Step Model Jel Classification: M40, M41

\footnotetext{
* Bu çalışma, Korten Tezel'in “TFRS 15 Müşteri Sözleşmelerinden Hasılat Standardına Geçişin Finansal Tablolara Etkileri: BİST 100 Endeksindeki Firmaların İncelenmesi” başlıklı yüksek lisans tezinden türetilmiştir. Makale Gönderim Tarihi: 21.05.2021, Makale Kabul Tarihi: 28.08.2021, Makale Türü: Nicel Araştırma

** İstanbul Bilgi Üniversitesi, Lisansüstü Programlar Enstitüsü, kortentezel@gmail.com, ORCID: 0000-00025901-6539.

*** Dr. Öğr. Üyesi, İstanbul Bilgi Üniversitesi, İşletme Fakültesi, derya.ucoglu@bilgi.edu.tr, ORCID: 00000001-5510-3574.
} 


\section{$\begin{array}{lll}\text { The Journal of Accounting and Finance- October } 2021 & \text { (92): 91-114 }\end{array}$}

\section{GİRIŞ}

Birçok büyük finansal skandal, uygun olmayan muhasebe politikaları kullanılarak hasılatın muhasebeleştirilmesi ile oluşan finansal manipülasyonların sonucu olduğundan, hasılatın muhasebeleştirilmesi muhasebe dünyası için son derece önemli bir konudur (Mirza ve Holt, 2011: 139).

Finansal piyasaların artan küreselleşmesine rağmen, Uluslararası Finansal Raporlama Standartları (UFRS) ve Amerikan Genel Kabul Görmüş Muhasebe İlkeleri'nin (GKGMI) hasılatla ilgili düzenlemelerinin önemli ölçüde farklılık göstermesi, işletmelerin finansal tablolarının karşılaştırılmasında tutarsızlıklara ve zorluklara neden olmuştur. UFRS'nin hasılatla ilgili hükümlerinin aşırı genel olması, önemli ve sorunlu konularda rehberlik yapmaktan uzak olması eleştirilere ve uygulamada zorluklara yol açmıştır. Diğer taraftan Amerikan GKGMI ise geniş kapsamlı olmakla beraber, konulara parçalı bir şekilde yaklaştığından, standardın kullanımı uygulayıcılara karmaşık gelmiştir (PWC, 2015: 1).

Daha önce hasılatla ilgili olarak iki ayrı standart (UMS 18 Hasılat ve UMS 11 İnşaat Sözleşmeleri) olması ve bu standartların hasılatın muhasebeleştirilmesinin zamanlaması, değişken bedel, paranın zaman değeri ve dipnotlarla ilgili zayıflıklarının ve tutarsızlıklarının bulunması (Collings, 2011) ve ayrıca UMS 18'de birçok başlıkla ilgili yetersiz yönlendirme olması (Epstein ve Jermakowicz, 2008: 226) nedeniyle UFRS uygulamasinda da hasılatın muhasebeleştirilmesi konusunda önemli ölçüde farklılıklar ortaya çıkmıştır.

$\mathrm{Bu}$ nedenle, daha yüksek kaliteli ve daha karşıllaştırılabilir bilgi sunmak amacıyla Uluslararas1 Muhasebe Standartları Kurulu (IASB) ve Amerikan Finansal Muhasebe Standartları Kurulu (FASB) tarafindan yürütülen ortak proje sonucunda UFRS 15 doğmuştur (Mattei ve Paoloni, 2019:169). Yeni hasılat standard1 1 Ocak 2018 tarihinden itibaren uygulanmak üzere yürürlüğe girerek eski hasılat ve inşaat sözleşmeleri standartlarının yerini almıştır (Ergüden, 2020: 48). Ayrıca UMS Yorum 31 Hasılat - Reklam Hizmetleri İçeren Takas (Barter) İşlemleri, UFRS Yorum 13 Müşteri Sadakat Programları, UFRS Yorum 15 Gayrimenkul İnşaat Anlaşmaları ve UFRS Yorum 18 Müşterilerden Varlık Transferleri yorumları da yürürlükten kaldırılmıştır (Şavlı, 2016: 22).

UFRS 15, yürürlükten kalkan UMS 18'deki eksiklikleri ortadan kaldırarak, hasılatın muhasebeleştirilmesi, ölçümü ve hasılata ilişkin dipnot açıklamaları ile ilgili olarak kuvvetli bir çerçeve sunmaktadır. UFRS 15'in müşteri sözleşmelerinden hasılatla ilgili karşılaştırılabilirliği artırması, hasılatın muhasebeleştirilmesi ile ilgili olarak ortaya çıkan hususları ele almak için vaka bazında geliştirilmesi gereken yorumlu rehberliğe olan ihtiyacı azaltması ve geliştirilmiş açıklama hükümleri ile daha faydalı bilgi sağlaması beklenmektedir (IFRS 15 Revenue From Contracts With Customers, Project Summary and Feedback Statement, 2014: 2).

UFRS 15, işletmeler tarafindan birçok tahmin yapılması ve kapsamlı muhakeme kullanımını gerektiren bir dizi ilkeye dayalı olarak, hasılatın muhasebeleştirilmesi ve dipnot açıklamalarını şekillendirmek amacıyla beş adımdan oluşan yeni bir model sunmaktadır. Yeni model, hasılatın hem miktarı hem de zamanlaması ile ilgili olarak önemli değişiklikler getirmektedir (Davern vd., 2019: 50). Hasılatın muhasebeleştirilmesi için kullanılan ilke bazlı 
bu beş adımlı model, işletmelerin edim yükümlülüklerinin ölçümü ve söz konusu edim yükümlülüklerinin yerine getirilmesinin zamanlamasıyla ilgili olarak daha fazla profesyonel yarg1 kullanımını da beraberinde getirmektedir (Rutledge vd., 2016: 44). Ancak diğer taraftan da TMS 18 'in yeterli yönlendirme yapamadığı değişken fiyatlama, çok unsurlu sözleşmeler, iade hakları ve garantiler ile lisanslama gibi konulara açıklık getirmektedir (Grant Thornton, 2017).

TFRS 15'in; hasılatın zamana yayılı olarak $\mathrm{m}$, belirli bir anda $\mathrm{m} 1$ muhasebeleştirileceği, sözleşmenin farklı mal ve hizmetler ve farklı teslimatlar içermesi durumunda hasılatın nasıl muhasebeleştirileceği ve sözleşmenin unsurlarına nasıl bölüneceği, sözleşmelerdeki değişikliklerin nasıl ele alınacağı, sözleşme maliyetlerinin nasıl (aktifleştirerek erteleme veya kar veya zarara yansıtma) muhasebeleştirileceği, sözleşmelerde finansman unsurunun yer alıp almadığının ve paranın zaman değerinin nasıl dikkate alınacağı ve zorunlu dipnot açıklamalarını yapabilmek için işletmelerin gerekli bilgilere sahip olup olmadıkları konularında işletmeleri etkilemesi muhtemeldir (Mahutova, 2021). Ancak yeni hasılat standardı ile ilgili olarak en ilgi çeken husus, farklı sektörlerde faaliyet gösteren firmaların beş adımlı modeli uygulamaları sonucunda finansal tablolarının nasıl etkileneceğidir.

Uzmanların görüşlerine göre, TFRS 15'in en çok telekomünikasyon, yazılım geliştirme ve teknoloji, yapı ve inşaat sektörleri ile üreticileri etkilemesi beklenmektedir (Calayoğlu ve Yılmaz, 2016:21). Bunun sebebi yap1 ve inşaat sektörünün uzun vadeli sözleşmeler yapması ve telekomünikasyon sektöründe de birden fazla mal veya hizmet içeren paket sözleşmeler bulunmasıdır (Boujelben ve Kobbi-Fakhfakh, 2020: 708).

TFRS 15, müşterilerine farklı ürün ve hizmetler içeren paketler sunan medya şirketleri ile malların kontrolünün devrine ilişkin değerlendirmelerine bağlı olarak hasılatı farklı bir zamanda muhasebeleştirmek zorunda kalabilecek madencilik işletmelerini de önemli ölçüde etkileyebilecektir (Deloitte, 2021). Dolayısıyla TFRS 15'e geçiş, mal ve hizmet teslimini anında yapıp bedelini peşin tahsil eden, sözleşmesiz satış yapan ve zamana yayılı yükümlülük taşımayan işletmeleri etkilemeyecektir (Calayoğlu ve Yılmaz, 2016: 18).

Aslında yeni hasılat standardının hasılatın muhasebeleştirilmesinin tutarı ve zamanlaması üzerindeki etkisinin boyutu, şirkete, işleme, sektöre ve yetki alanına bağlı olarak farklılık gösterebilecektir. Bazı durumlarda ise muhasebeleştirilen gelirin tutarında ve zamanlamasında herhangi bir değişiklik olmaması beklenmektedir (McConnell, 2014: 2).

Bu çalışmanın amacı TFRS 15 Müşteri Sözleşmelerinden Hasılat standardına geçişin, geçiş yılı olan 2018 yılı itibariyle BİST 100'de yer alan işletmelerin finansal tablolarına etkilerinin belirlenmesidir. Çalışma, yeni standardın hem finansal durum hem de finansal performansa önemli etkileri olup olmadığının, önemli etkinin varlığı konusunda işletmelerin gerekli dipnot açıklamalarını yapıp yapmadıklarının ve yeni hasılat standardına geçişin sektörler ve işletmeler üzerindeki finansal etkilerinin, dipnot açıklamaları incelenerek gerekçeleri ile irdelenmesini kapsamaktadır. 


\section{$\begin{array}{lll}\text { The Journal of Accounting and Finance- October } 2021 & \text { (92): } 91-114\end{array}$}

\section{LITERATÜR TARAMASI}

Literatürde TFRS/UFRS 15 'in getirdiği yeniliklerle ilgili ve yeni hasılat standard1 kapsamında hasılatın nasıl muhasebeleştirileceği hususunda yapılmış birçok çalışma mevcuttur.

Keskin ve Dinçer (2015), beş adım yaklaşımının özellikleri ve hasılatın nasıl muhasebeleştirileceği konusunda yaptıkları çalışmada, telekomünikasyon sektörüne ilişkin bir uygulamaya yer verirken, Mert ve Baş (2017), faktoring işletmelerinin elde ettiği gelir getirici unsurların TMS 18 ve TFRS 15 kapsamında nasıl muhasebeleştirileceğini incelemiştir. Çalış (2019) çalışmasında TFRS 15'i, BOBİ FRS Bölüm 5 düzenlemeleri ve vergi kanunlarıyla karşılaştırmış, benzerliklerini ve farklılıklarını bir uygulama ile karşılaştırmalı şekilde ortaya koymuştur. Benzer şekilde Memiş (2019) de, hasılatın muhasebeleştirilmesi konusunda MSUGT, TMS/TFRS ve BOBİ FRS'yi karşılaştırmalı olarak incelemiştir. Gündüz ve Yanık (2020) ise, inşaat sektörüne odaklanan bir çalışma yapmış ve yıllara yaygın inşaat taahhüt işleriyle ilgili örnek bir uygulama ile farklı edim yükümlülüklerine sahip sözleşmelerin muhasebeleştirilmesinin finansal tablolara etkilerini göstermiştir.

UFRS 15'e geçişin hisse senedi fiyatlarına etkileri, yeni standarda geçiş sürecinde denetçilerin rolleri ve geçişle ilgili öngörülen zorluklar konusunda yapılmış önemli çalışmalar bulunmaktadır.

Aladwan (2019) yaptığı çalışmada, UFRS 15'in erken uygulanmasının Ürdün firmalarının hasılat seviyesini ve hisse senedi fiyatlarını etkileyip etkilemediğini incelemiştir. Amman borsasında faaliyet gösteren 23 işletme üzerinde yapılan araştırma sonuçlarına göre hem hasılat tutarlarında hem de hisse senedi fiyatlarında UFRS 15'in uygulanmasıyla birlikte önemli farklılıklar oluştuğu ve standardın uygulanmasının söz konusu kalemleri negatif etkilediği belirlenmiştir.

Davern vd. (2019), UFRS 15'in uygulanma sürecinde yer alan 143 finansal tablo hazırlayıcısı ile gerçekleştirdikleri ankette işletmelerin UFRS 15 'in uygulanması için tanınmış olan ek süreden faydalanmadıklarını, bunu sadece gerekli uyum çalışmalarına daha geç başlamak için firsat olarak gördüklerini belirlemiştir. Daha kaliteli bilgi sayesinde işletmelerin daha iyi yönetilmesi gibi yeni bir standardı uygulamanın işletmelere sağlayacağı faydaların standart koyucular tarafından vurgulanmasının işletmeleri standardı uygulama konusunda daha fazla teşvik edeceğini belirlemiştir. Ayrıca işletmeler, denetçiler, standart belirleyiciler, düzenleyici gözetim kurumlarının hem raporlamada bütünlüğü sağlayan hem de iş başarısını artıran etkili finansal raporlama sunmak için güçlü rol oynamaları gerektiği sonucuna varılmıştır.

Altaji ve Alokdeh (2019), UFRS 15'in ihtiyaca uygunluk ve gerçeğe uygun sunum bakımından finansal bilgi kalitesi üzerindeki etkisini araştırmak için Ürdün'deki Big Four denetim firmalarında çalışan 100 denetçiye anket yapmıştır. Çalışma sonuçları, dış denetçilerin bakış açısıyla, finansal bilgilerin kalitesinin iyileştirilmesinde UFRS 15'in uygulanmasının istatistiksel olarak önemli bir etkisi olduğunu göstermektedir. Ancak dış denetçilere göre UFRS 15, getirdiği yeni muhasebeleştirme ve açıklama gereklilikleri, 
işletmeler için bilgi teknolojisi değişikliklerinin yapılması, ilgili iç kontrollerin oluşturulması ve nitelikli insan kaynağı istihdamının sağlanması gibi zorluklar yaratmaktadır.

Kohler, Pochet ve Manh (2021) ise, telekomünikasyon sektöründe UFRS 15’in içselleştirilmesi ve standardın nihai haline getirilmesinde aracı olarak denetçilerin rolü üzerine bir çalışma gerçekleştirmiştir. Çalışma sonucunda denetçilerin süreçte kilit bir rol oynadığ 1 ve denetçilerin telekomünikasyon şirketleri ile IASB arasındaki görüşmelere aracılık etme gündemlerinin, standartları denetlenebilir tutmaya odaklandığı görülmüştür. UFRS 15 kapsamındaki beş aşamalı hasılat muhasebeleştirme modelinin uygulanmasının ve denetlenmesinin önceki standartlara göre çok daha karmaşık olduğu ve bunun da denetim işini ve ücretlerini artırabileceği belirlenmiştir.

$\mathrm{Bu}$ çalışmanın konusunu oluşturan ve TFRS/UFRS 15'e geçişin finansal etkilerinin değerlendirildiği çalışmaların sayısı oldukça azdır. Bu nedenle BİST 100 endeksi üzerinde yapılan bu çalışmanın literatüre önemli katkısının olacağı düşünülmektedir.

Özerhan ve Sultanoğlu (2019), UFRS 15'in yazılım şirketlerine etkisini BİST'te işlem gören 16 yazılım şirketi ve yabancı piyasalarda işlem gören işletmeler açısından karşılaştırmalı şekilde değerlendirmek üzere bir çalışma gerçekleştirmiştir. Çalışma bulgularına göre, BİST'teki işletmelerin yeni standardın hasılatın muhasebeleştirilmesine ilişkin olarak önemli bir değişikliğe neden olmadığını açıkladıkları, yabancı işletmelerin ise tam tersi şekilde UFRS 15'in hasılatın muhasebeleştirilmesinde önemli değişiklikler yarattığını açıkladıkları görülmüştür.

Ünlütürk, Deveci ve Dağlı (2019) yaptıkları çalışmada, TFRS 15 çerçevesinde hasılatın ölçülmesini ve BİST 50'de işlem gören işletmelerde standardın etkilerini değerlendirmiştir. BİST 50'de yer alan işletmelerden 12'si TFRS 15 ile ilgili olarak hiç açıklama yapmazken, 23 işletme önemli etkisi olmadığını ve 15 işletme ise TFRS 15 'e geçişin önemli etki yarattığını açıklamıştır.

Boujelben ve Kobbi-Fakhfakh (2020), UFRS 15 dipnot açıklamaları ile ilgili olarak yaptıkları çalışmada, telekomünikasyon ve inşaat sektörlerinde faaliyet gösteren, Avrupa Birliği'nde halka açık 22 işletmenin raporlarına içerik analizi uygulamıştır. İlk uygulama yılı olan 2018 yılsonu raporlarına göre, zorunlu UFRS 15 açıklamalarına tamamıyla uyumun mevcut olmadığı, inşaat sektöründe faaliyet gösteren işletmelerin de telekomünikasyon sektöründeki gruplara göre daha az UFRS 15 açılaması yaptıkları tespit edilmiştir.

Ergüden (2020), BİST’te işlem gören turizm ve otel işletmelerinin TFRS 15 dipnot açıklamaları ile ilgili içerik analizi yaptığı çalışmasında, standart hükümlerine kıyasla eksik ve yetersiz açıklamalar yapıldığını belirlemiştir. Dipnotlarda daha çok beş adım modeli gibi hususlarda genel açıklamalara yer verildiği, edim yükümlülükleri veya kalan edim yükümlülüklerine dağıtılan işlem bedelleri gibi konularda açıklamaların pek yer almadığı görülmüştür.

Napier ve Stadler (2020), UFRS 15'in etkilerini belirlemek amaciyla STOXX Europe 50 endeksindeki 48 firmanın 2018 yılı raporlarını incelemiş ve ayrıca bir denetçi, bir finansal tablo hazırlayıcısı ve bir danışmanla olmak üzere üç tane yarı yapılandırılmış mülakat 


\section{The Journal of Accounting and Finance- October 2021 (92): 91-114}

gerçekleştirmiştir. Çalışma sonuçlarına göre birkaç sektör (özellikle telekomünikasyon) dışında UFRS 15'e geçişin Avrupa'nın en büyük işletmelerinin çoğunun finansal rakamlarına etkisinin oldukça az olduğu, ancak UFRS $15^{\prime}$ 'e geçişle birlikte genel olarak dipnot açıklamalarının arttığı görülmüştür.

Vaicekauskas (2020), Litvanya'daki 31 halka açık işletmenin finansal tablo ve dipnotlarını kullanarak içerik analizi yapmış ve UFRS 15'in ilk kez uygulanmasının Litvanya borsasında işlem gören şirketlerin finansal tabloları üzerinde önemli bir etkisi olmadığını belirlemiştir.

Quagli, Roncagliolo ve D’Alauro (2021) ise, 153 Avrupa firması ile ilgili yaptıkları çalışmada yeni hasılat standardının uygulanması ile ilgili beklenen etkiler hakkında yapılan açıklamaları hangi faktörlerin belirlediğini incelemiştir. Karlılığın ve faaliyet bölümü sayısı ile ölçülen iş karmaşıklığının önemli faktörler olduğu ve karlılığı daha yüksek ve daha fazla faaliyet bölümü olan işletmelerin UFRS 15 ile ilgili hazırlık yapmak ve yeni standardın potansiyel etkilerinin farkında olmak için daha fazla teşviğe sahip oldukları belirlenmiştir. Ayrıca büyük firmaların da beklenen etki konusunda daha fazla açıklama yaptıkları ortaya koyulmuştur.

\section{YENI HASILAT STANDARDINA GEÇIŞİN FINANSAL TABLOLARA ETKILERI}

\section{1. Çalışmanın Amacı, Kapsamı Ve Yöntemi}

TFRS 15 Müşteri Sözleşmelerinden Hasılat standardı Resmi Gazete'de yayımlanarak 1 Ocak 2018 tarihinden sonra başlayan dönemlerde uygulanmak üzere yürürlüğe girmiştir.

$\mathrm{Bu}$ çalışmanın amacı, TFRS 15'e ilk geçişin finansal tablolara etkilerinin tespit edilmesidir. Bu doğrultuda BİST 100 endeksinde yer alan firmaların 31 Aralık 2018 tarihli yıllık finansal raporları ve dipnotları KAP'tan indirilerek kullanılmış ve yıl sonu raporları içerik analizine tabi tutulmuştur. ${ }^{1}$ İçerik analizi, finansal muhasebe araştırmalarında (Beattie, 2005: 106) ve finansal tablo açıklamalarının incelenmesini içeren araştırmalarda (Chang, 2018: 512) yaygın olarak kullanılan bir yöntemdir.

$\mathrm{Bu}$ çalışmada yapılan analizin temeli, TFRS $15^{\prime}$ 'in C8 paragrafinda yer alan açıklama hükümlerine dayanmaktadır. TFRS 15 'i geriye dönük uygulayan işletmelerin "değişiklik öncesi yürürlükteki TMS 11, TMS 18 ve ilgili Yorumlar ile bu Standardın uygulanmas1 karşılaştırıldığında, cari raporlama dönemindeki her bir finansal tablo kaleminin etkilenme tutarı"nı açıklamaları gerekmektedir. Bu doğrultuda 31 Aralık 2018 tarihli söz konusu açıklamalar kullanılarak, TMS 11 ve TMS 18'den TFRS 15'e geçişin hangi finansal tablo kalemlerini ne ölçüde etkilediğinin belirlenmesi amaçlanmaktadır.

Alternatif olarak, 2017 yıl sonu (eski standartların kullanıldığı son y1l) ve 2018 yıl sonu (yeni standardın uygulandığı ilk yıl) raporlarındaki finansal verilerin karşılaştırılarak yeni standardın etkisinin tespit edilmeye çalışılması, çalışmanın sonuçları bakımından

\footnotetext{
${ }^{1}$ Yıl sonu 31 Aralık olmayan işletmelerin, TFRS 15 uygulamaya başladıkları ilk tam yıl raporları dikkate alınmıştır.
} 
yanıltıcı olacaktır. Çünkü 2017 ve 2018 yılları arasında hasılat ve diğer kalemlerdeki değişimlerin, yeni hasılat standardına geçiş dışında birçok farklı etkenden (ekonomik kriz, teknolojik gelişmeler nedeniyle ürün/hizmet talebindeki artış/azalış, firmanın genel finansal durumundaki değişimler, sektöre yeni rakiplerin girmesi veya sektörden çıkan firmalar olmas1, vb.) kaynaklanması mümkündür ve her değişkenin finansal verilere etkilerinin belirlenmesi ve yeni hasılat standardına geçişin etkilerinden ayrıştırılması mümkün değildir.

TFRS 15, UFRS 15, hasılat gibi anahtar kelimeler kullanılarak yapılan içerik analizi sonucunda her işletmenin TFRS 15'e geçişten etkilenen kalemleri ile her kalemin TFRS 15 öncesi ve TFRS 15 sonrası tutarları özetlenmiş ve değişimin etkisini ortaya koyabilmek amaciyla değişim yüzdeleri hesaplanmıştır. Daha sonra söz konusu değişimlerin gerekçelerinin tespit edilebilmesi amaciyla ilgili kalemlere ait dipnotlar ve TFRS 15'le ilgili olarak yapılmış bütün açıklamalar detaylıca incelenmiştir. Son olarak da TFRS 15'e geçişle birlikte belirli kalemlerde ortaya çıkan değişimlerin istatistiksel olarak anlamlı olup olmadığının belirlenmesi için ilişkili (bağımlı) örnekler t testleri yapılmıştır.

TFRS 15 'e geçişin etkisinin belirlenmesi amacıyla, BİST 100'de yer alan ve çalışma kapsamında incelenen firmaların sektörel dağılımı aşağıda yer almaktadır:

Tablo 1. BİST 100’de Yer Alan Firmaların Sektörel Dağılımı

\begin{tabular}{|l|c|}
\hline Sektör & Firma Sayısı \\
\hline Eğitim, Sağlık, Spor ve Diğer Sosyal Hizmetler & 5 \\
\hline Elektrik Gaz ve Su & 4 \\
\hline Gayrimenkul Faaliyetleri & 1 \\
\hline İmalat Sanayii & 39 \\
\hline İnsaat ve Bayındırlık & 1 \\
\hline Madencilik & 4 \\
\hline Mali Kuruluşlar & 34 \\
\hline Teknoloji & 3 \\
\hline Toptan ve Perakende Ticaret, Otel ve Lokantalar & 4 \\
\hline Ulaştırma, Haberleşme ve Depolama & 5 \\
\hline TOPLAM & $\mathbf{1 0 0}$ \\
\hline
\end{tabular}

\section{2. Çalışmanın Bulguları}

BİST 100'de yer alan firmaların TFRS 15'e geçişle ilgili olarak yaptıkları dipnot açıklamaları içerik analizine tabi tutulmuş ve yeni hasılat standardına geçişle ilgili olarak yaptıkları açıklamalar aşağıdaki tabloda özetlenmiştir. 
The Journal of Accounting and Finance- October 2021 (92): 91-114

Tablo 2. BİST 100'de Yer Alan Firmaların TFRS 15'e Geçişle İlgili Açıklamaları

\begin{tabular}{|l|c|c|c|c|}
\hline Sektör & $\begin{array}{c}\text { Açılkama } \\
\text { Yok }\end{array}$ & Etki Var & $\begin{array}{c}\text { Önemli Etki } \\
\text { Yok }\end{array}$ & Toplam \\
\hline $\begin{array}{l}\text { Eğitim, Sağlik, Spor ve Diğer Sosyal } \\
\text { Hizmetler }\end{array}$ & - & - & 5 & 5 \\
\hline Elektrik Gaz ve Su & - & 1 & 3 & 4 \\
\hline Gayrimenkul Faaliyetleri & - & - & 1 & 1 \\
\hline İmalat Sanayii & 7 & 7 & 25 & 39 \\
\hline İnşaat ve Bayındırlık & - & - & 1 & 1 \\
\hline Madencilik & 3 & - & 1 & 4 \\
\hline Mali Kuruluşlar & 9 & 3 & 22 & 34 \\
\hline Teknoloji & 1 & 2 & - & 3 \\
\hline $\begin{array}{l}\text { Toptan ve Perakende Ticaret, Otel ve } \\
\text { Lokantalar }\end{array}$ & - & - & 4 & 4 \\
\hline Ulaştırma, Haberleşme ve Depolama & - & 4 & 1 & 5 \\
\hline TOPLAM & $\mathbf{2 0}$ & $\mathbf{1 7}$ & $\mathbf{6 3}$ & $\mathbf{1 0 0}$ \\
\hline
\end{tabular}

BİST 100'de yer alan 20 işletme TFRS 15'e geçişle ilgili hiçbir açıklama yapmamış olup, söz konusu işletmelerin bazılarının raporlarında TFRS 15 veya UFRS 15 kelimelerinin bile geçmediği görülmüştür. Bu işletmeler ağırlıkla imalat sanayinde ve mali sektörde faaliyet göstermektedir. Benzer şekilde TFRS 15 'e geçişin etkilerinin değerlendirildiğini ve finansal tablolara önemli bir etkisinin olmadığının tespit edildiğini açıklayan 63 işletmenin de büyük çoğunluğu imalat sanayinde ve mali sektörde faaliyet göstermektedir. TFRS 15 'e geçişin etkilerini toplam 17 firma dipnot açıklamalarında sunmuştur. Ancak Vestel Elektronik San. ve Tic. A.Ş. yapılan çalışmaya dahil edilememiştir. Bunun nedeni de firmanın TFRS 15 ve TFRS 9'a geçişin etkilerini toplam olarak tek kalemde sunmuş olmasıdır. İki standardın etkisinin birlikte sunulmuş olması nedeniyle de TFRS 15 kapsamında bireysel değerlendirme yapmak mümkün olmamıştır.

TFRS 15'e geçiş hükümlerinde işletmelere sunulan iki alternatif yöntem bulunmaktadır. Birinci yöntem TMS 8 Muhasebe Politikaları, Muhasebe Tahminlerinde Değişiklikler ve Hatalar standardı kapsamında işletmelerin sunulan her geçmiş raporlama dönemi için TFRS 15'i geriye dönük olarak uygulamasıdır. Diğer yöntem de Standardın ilk uygulama tarihinde, Standardın ilk defa uygulanmasından kaynaklanan kümülatif etkiyle geriye dönük olarak uygulanmasıdır. Yani işletmeler TFRS 15'in ilk kez uygulanması sonucunda ortaya çıkan kümülatif etkiyi, ilk uygulama tarihini kapsayan yılık raporlama dönemine ilişkin geçmiş yıllar karları hesabının veya uygun diğer bir özkaynak hesabının açılış bakiyesinde fark düzeltmesi olarak finansal tablolara almalıdır (TFRS 15, Ek C). 
Tablo 3. BIST 100'de Yer Alan Firmaların TFRS 15'e Geçişle İlgili Kullandıkları Yöntem Açıklamaları

\begin{tabular}{|l|c|c|}
\hline Sektör & Tam geriye dönük & $\begin{array}{c}\text { Kolaylaştırılmış } \\
\text { (modifiye edilmiş) } \\
\text { geriye dönük yöntem } \\
\text { (kümülatif etki) }\end{array}$ \\
\hline Ĕ̆itim, Sağlık, Spor ve Diğer Sosyal Hizmetler & - & 2 \\
\hline Elektrik Gaz ve Su & - & 3 \\
\hline Gayrimenkul Faaliyetleri & - & - \\
\hline İmalat Sanayii & - & 18 \\
\hline İnşaat ve Bayındırlık & - & - \\
\hline Madencilik & - & - \\
\hline Mali Kuruluşlar & 1 & 8 \\
\hline Teknoloji & 1 & 1 \\
\hline Toptan ve Perakende Ticaret, Otel ve Lokantalar & 1 & 1 \\
\hline Ulaştırma, Haberleşme ve Depolama & - & 4 \\
\hline TOPLAM & $\mathbf{3}$ & $\mathbf{3 7}$ \\
\hline
\end{tabular}

$\mathrm{Bu}$ doğrultuda TFRS 15 'e geçişle ilgili işletmelerin açıkladıkları yöntemler için yapılan içerik analizinde, işletmelerden üçünün tam geriye dönük uygulamayı ve 37 işletmenin de kolaylaştırılmış (modifiye edilmiş) geriye dönük yöntemi kullanarak kümülatif etkiyi özkaynaklarda ilgili hesabın açılış bakiyesinde bir fark düzeltmesi olarak sunmayı tercih ettikleri konusunda açıklama yaptıkları, diğer işletmelerin ise bu konuda herhangi bir açıklama yapmadıkları belirlenmiştir. TFRS 15 'e geçişin finansal tablolara etkilerini önemli olarak değerlendiren ve dipnotlarında finansal tablo kalemlerine etkilerini açıklayan toplam 17 işletmenin 16'sı kolaylaştırılmış (modifiye edilmiş) geriye dönük yöntem (kümülatif etki) kullandığını açıklarken, tam geriye dönük uygulama yapan ve önemli etki açıklayan işletme sayısı 1'dir. Tam geriye dönük uygulamayı tercih eden diğer 2 işletme ise TFRS 15 'e geçişin finansal tablolarda önemli bir etkisi olmadığını açıklamıştır.

2018 y1l sonu raporlarına ait dipnotlarda açıklanan veriler kullanılarak, beş farklı sektörde faaliyet gösteren 16 işletmeye ait finansal tablo kalemlerinin TFRS 15 öncesi ve TFRS 15 etkisi dahil kümülatif rakamları baz alınarak TL olarak değişim ve değişim yüzdeleri hesaplanmış ve Tablo 4'te sunulmuştur. Aynı tarih itibariyle hem eski standartlar (TMS 11 ve TMS 18) hem de yeni hasılat standardı (TFRS 15) uygulanarak açıklanmış olan bu rakamlar, yeni standarda geçişin etkisinin net bir şekilde belirlenmesini sağlamaktadır. 
The Journal of Accounting and Finance- October 2021 (92): 91-114

Tablo 4. TFRS 15 Uygulamasına Geçiş ile Birlikte Finansal Tablo Kalemlerinde Meydana Gelen Toplam Değişimler

\begin{tabular}{|l|c|c|c|c|}
\hline Finansal Tablo Kalemleri & $\begin{array}{c}\text { TFRS 15 Öncesi } \\
\text { Toplam Tutar } \\
\text { (TL) }\end{array}$ & $\begin{array}{c}\text { TFRS 15 } \\
\text { Sonrası Toplam } \\
\text { Tutar (TL) }\end{array}$ & Değişim (TL) & $\begin{array}{c}\text { Değişim } \\
\text { Yüzdesi }\end{array}$ \\
\hline Ticari Alacaklar & 15.749 .760 .698 & 15.688 .385 .353 & -61.375 .345 & $-\% 0,39$ \\
\hline $\begin{array}{l}\text { Devam Eden Sözleşmelere İlişkin } \\
\text { Varlıklar }\end{array}$ & 279.442 .270 & 305.680 .684 & 26.238 .414 & $\% 9,39$ \\
\hline Stoklar & 4.843 .145 .000 & 4.838 .231 .000 & -4.914 .000 & $-\% 0,10$ \\
\hline Peşin Ödenmiş Giderler & 622.434 .000 & 473.588 .000 & -148.846 .000 & $-\% 23,91$ \\
\hline $\begin{array}{l}\text { Özkaynak Yöntemiyle Değerlenen } \\
\text { Yatırımlar }\end{array}$ & 18.680 .667 .092 & 18.666 .861 .478 & -13.805 .614 & $-\% 0,07$ \\
\hline MODV & 17.704 .063 .000 & 19.788 .267 .000 & 2.084 .204 .000 & $\% 11,77$ \\
\hline KVYK & 33.633 .093 .153 & 34.082 .436 .849 & 449.343 .696 & $\% 1,34$ \\
\hline UVYK & 2.414 .099 .713 & 2.683 .323 .621 & 269.223 .908 & $\% 11,15$ \\
\hline Hasılat & 360.361 .406 .490 & 360.217 .072 .877 & -144.333 .613 & $-\% 0,04$ \\
\hline Satı̧ların Maliyeti & -103.712 .017 .768 & -103.952 .762 .512 & -240.744 .744 & $\% 0,23$ \\
\hline Brüt Kar & 38.113 .064 .722 & 37.727 .986 .365 & -385.078 .357 & $-\% 1,01$ \\
\hline Net Kar/Zarar & 23.197 .006 .474 & 23.351 .775 .211 & 154.768 .737 & $\% 0,67$ \\
\hline
\end{tabular}

Ortalama değişim yüzdeleri incelendiğinde devam eden sözleşmelere ilişkin varlıklar, peşin ödenmiş giderler, maddi olmayan duran varlık (MODV) ve uzun vadeli yabancı kaynaklar (UVYK) en çok etkilenen kalemler olarak belirlenmiştir. Ancak bazı kalemlerdeki toplam değişimin, yalnızca bir veya birkaç işletmedeki değişimin toplamını gösterdiği ve farklı sektörlerdeki farklı işletmelerin ilgili kalemlerdeki değişimlerinin toplam içindeki katkılarının farklı olduğu dikkate alındığında, TFRS 15'e geçişin etkilerini yorumlarken tek başına toplam değişim ve toplam yüzdesel değişimin anlamlı olmayacağı da unutulmamalıdır.

TFRS 15'e geçişin etkilerinin sektörler bazında da farklılık gösterebileceği dikkate alınarak, Tablo 5'te finansal tablo kalemlerindeki değişimler sektörel olarak özetlenmiştir. Öncelikle TFRS 15 öncesi ve sonrası rakamlar arasındaki fark hesaplanarak geçişin sektör bazında kalemlere net etkisi belirlenmiştir. Hesaplanan TL değişim, TFRS 15 öncesi rakamlara bölünerek yüzdesel değişimler hesaplanmıştır. Yeni hasılat standardına geçişin en az etkilediği sektör elektrik, gaz ve su sektörü olarak görülmektedir. Göreceli olarak en çok etkilenen sektörlerin de imalat sanayii, teknoloji ve ulaştırma, haberleşme ve depolama sektörleri olduğu belirlenmiştir.

Benzer sonuçlara ulaşılan ve teknoloji, yazılım ve telekomünikasyon firmalarının yeni hasılat standardından en çok etkilenen sektörler olacağı beklentisini içeren çalışmalar da mevcuttur (Ciesielski ve Weirich, 2015: 31; Aktaş ve Varol, 2017: 29).

Ayrıca elektrik, gaz ve su sektöründe yeni hasılat standardına geçiş yalnızca hasılat ve satışların maliyeti kalemlerinde önemsiz etki yaratırken, diğer sektörlerde çok daha fazla finansal tablo kaleminin etkilendiği görülmektedir. 
Tablo 5. TFRS 15 Uygulamasına Geçiş ile Birlikte Bazı Finansal Tablo Kalemlerinde Meydana Gelen Yüzdesel Değişimlerin Sektörel Dağılımı

\begin{tabular}{|l|c|c|c|c|c|}
\hline & $\begin{array}{c}\text { Elektrik } \\
\text { Gaz ve Su }\end{array}$ & $\begin{array}{c}\text { İmalat } \\
\text { Sanayii }\end{array}$ & $\begin{array}{c}\text { Mali } \\
\text { Kuruluşlar }\end{array}$ & Teknoloji & $\begin{array}{c}\text { Ulasstırma, } \\
\text { Haberleşme } \\
\text { ve Depolama }\end{array}$ \\
\hline Ticari Alacaklar & - & $\% 2,40$ & $-\% 1,60$ & $-\% 5,10$ & $-\% 0,12$ \\
\hline $\begin{array}{l}\text { Devam Eden Sözleşmelere İlişkin } \\
\text { Varlıklar }\end{array}$ & - & - & - & $\% 9,39$ & - \\
\hline Stoklar & - & $-\% 2,44$ & $\% 1,38$ & - & - \\
\hline Peşin Ödenmiş Giderler & - & - & - & - & $-\% 23,91$ \\
\hline $\begin{array}{l}\text { Özkaynak Yöntemiyle Değerlenen } \\
\text { Yatırımlar }\end{array}$ & - & - & $-\% 0,07$ & - & - \\
\hline MODV & - & - & - & - & $\% 11,77$ \\
\hline KVYK & - & $\% 4,28$ & $\% 0,53$ & $\% 2,39$ & $\% 1,36$ \\
\hline UVYK & - & $\% 43,84$ & $\% 5,95$ & - & $\% 27,24$ \\
\hline Hasılat & $-\% 0,18$ & $\% 0,09$ & $-\% 0,07$ & $\% 1,18$ & $-\% 0,06$ \\
\hline Satışların Maliyeti & $-\% 0,26$ & $\% 0,28$ & $-\% 0,81$ & $\% 1,35$ & $\% 0,47$ \\
\hline Brüt Kar & - & $\% 0,82$ & $-\% 0,40$ & $-\% 0,05$ & $-\% 1,79$ \\
\hline Net Kar/Zarar & - & $-\% 0,54$ & $-\% 0,45$ & $\% 64,77$ & $\% 4,41$ \\
\hline
\end{tabular}

Daha detaylı bir analiz yapılabilmesi amacıyla, BİST 100'de yer alan 16 işletme için TFRS 15'e geçişin varlıklara etkileri Tablo 6'da özet olarak sunulmuştur. Yeni hasılat standardına geçişin varlıklara toplam etkisinin aktif toplamına olan oranları değerlendirildiğinde, en çok etkilenen sektörlerin teknoloji ile ulaştırma, haberleşme ve depolama sektörleri olduğu görülmektedir.

Ulaştırma, haberleşme ve depolama sektöründeki en belirgin değişimin Turkcell İletişim Hizmetleri ve Türk Telekomünikasyon firmalarında olduğu görülmektedir. Her iki işletmenin de TFRS 15 'e geçişle birlikte maddi olmayan duran varlıklarında \%2,5-3 civarında artış olduğu görülmektedir. Söz konusu artışın sebebi abone kazanma/edinme ve tutma maliyetleridir. Daha önce TMS 18 kapsamında oluştukları yılda kar veya zararda muhasebeleştirilen bu maliyetler, sözleşme yapılmamış olması durumunda katlanılması gerekmeyen bayi satış komisyonları, yasal giderler gibi maliyetlerdir. Abone kazanmak amacıyla peşin ödenen giderler ise, güvenilir bir şekilde tutarın ölçülebilmesi, abonenin belirli bir süre boyunca bağlanmasını sağlayan bir kontratın bulunması, aktifleştirilen giderlerin abonelik sözleşmesiyle ilgili hasılat aracılığıyla geri kazanılabilir olması veya abonenin kontrat süresi dolmadan aboneliğini sonlandırması durumunda cayma bedeli tahsil edilebilmesi koşullarının sağlanması durumunda peşin ödenmiş giderler olarak finansal tablolara alınmakta ve abonelik sözleşmesinin asgari süresi boyunca doğrusal yöntem ile pazarlama giderleri olarak itfa edilmekteydi. Ancak TFRS 15'e geçilmesiyle birlikte abone edinme maliyetleri, söz konusu maliyetlerin yalnızca müşteriyle sözleşme yapılması durumunda katlanılacak maliyetler olması durumunda ve geri kazanılmaları bekleniyorsa, sözleşme yapılması için katlanılan ek maliyetler olarak aktifleştirilmekte ve genelde maddi olmayan duran varlık olarak raporlanmaktadır. Abone edinme maliyetleri abone ömrü boyunca ve abone tutma maliyetleri de yenileme dönemi boyunca itfa edilmekte ve itfa payları pazarlama, satış ve dağıtım giderlerinde sınıflandırılmaktadır. 
The Journal of Accounting and Finance- October 2021 (92): 91-114

Tablo 6. TFRS 15'e Geçişin Varlıklara Etkileri (TL)

\begin{tabular}{|c|c|c|c|c|c|c|c|c|c|}
\hline & $\begin{array}{c}\text { Ticari } \\
\text { Alacaklara } \\
\text { Etkisi }\end{array}$ & $\begin{array}{l}\text { Devam Eden } \\
\text { Sözleşmelere } \\
\text { Illişkin } \\
\text { Varlıklara } \\
\text { Etkisi }\end{array}$ & $\begin{array}{l}\text { Stoklara } \\
\text { Etkisi }\end{array}$ & $\begin{array}{l}\text { Peşin } \\
\text { Ödenmiş } \\
\text { Giderlere } \\
\text { Etkisi }\end{array}$ & $\begin{array}{c}\text { Özkaynak } \\
\text { Yöntemiyle } \\
\text { Değerlenen } \\
\text { Yatırımlara } \\
\text { Etkisi }\end{array}$ & $\begin{array}{l}\text { MODV'ye } \\
\text { Etkisi }\end{array}$ & $\begin{array}{c}\text { Aktife } \\
\text { Toplam Etkisi }\end{array}$ & Aktif Toplamı & $\begin{array}{c}\text { Toplam } \\
\text { Etki/Aktif } \\
\text { Toplamı }\end{array}$ \\
\hline Elektrik Gaz ve Su & $\mathbf{0}$ & $\mathbf{0}$ & $\mathbf{0}$ & $\mathbf{0}$ & $\mathbf{0}$ & $\mathbf{0}$ & $\mathbf{0}$ & 23.125.041.000 & $\% 0,0000$ \\
\hline ENERJISA ENERJİ A.Ş. & 0 & 0 & 0 & 0 & 0 & 0 & 0 & 23.125 .041 .000 & $\% 0,0000$ \\
\hline İmalat Sanayii & 60.391 .997 & $\mathbf{0}$ & -45.810 .000 & $\mathbf{0}$ & $\mathbf{0}$ & $\mathbf{0}$ & 14.581.997 & 76.129.485.980 & $\% 0,0192$ \\
\hline ANADOLU CAM SANAYIII A.Ş. & 2.543 .000 & 0 & -905.000 & 0 & 0 & 0 & 1.638 .000 & 5.001 .782 .000 & $\% 0,0327$ \\
\hline ARÇELIK A.Ş. & 0 & 0 & 0 & 0 & 0 & 0 & 0 & 28.368 .361 .000 & $\% 0,0000$ \\
\hline $\begin{array}{l}\text { KARTONSAN KARTON SANAYİ VE } \\
\text { TİCARET A.Ş. }\end{array}$ & -528.003 & 0 & 0 & 0 & 0 & 0 & -528.003 & 487.898 .980 & $-\% 0,1082$ \\
\hline PETKİM PETROKIMMYA HOLDİNG A.Ş. & 0 & 0 & 0 & 0 & 0 & 0 & 0 & 12.587 .806 .000 & $\% 0,0000$ \\
\hline SODA SANAYIII A.Ş. & 61.614 .000 & 0 & -47.395 .000 & 0 & 0 & 0 & 14.219 .000 & 6.369.058.000 & $\% 0,2233$ \\
\hline $\begin{array}{l}\text { TOFAŞ TÜRK OTOMOBİL FABRİKASI } \\
\text { A.Ş. }\end{array}$ & 0 & 0 & 0 & 0 & 0 & 0 & 0 & 13.001.799.000 & $\% 0,0000$ \\
\hline TRAKYA CAM SANAYIII A.Ş. & -3.237 .000 & 0 & 2.490 .000 & 0 & 0 & 0 & -747.000 & 10.312 .781 .000 & $-\% 0,0072$ \\
\hline Mali Kuruluşlar & -57.807 .780 & $\mathbf{0}$ & 40.896.000 & $\mathbf{0}$ & -13.805 .614 & $\mathbf{0}$ & -30.717 .394 & 155.301.447.969 & $-\% 0,0198$ \\
\hline KOÇ HOLDİNG A.Ş. & 0 & 0 & 0 & 0 & -3.237 .000 & 0 & -3.237 .000 & 125.275 .881 .000 & $-\% 0,0026$ \\
\hline POLISAN HOLDİNG A.Ş. & -6.286 .780 & 0 & 0 & 0 & -10.568 .614 & 0 & -16.855 .394 & 2.258 .010 .969 & $-\% 0,7465$ \\
\hline $\begin{array}{l}\text { TÜRKIYYE ŞİŞE VE CAM } \\
\text { FABRIKALARI A.Ş. }\end{array}$ & -51.521 .000 & 0 & 40.896 .000 & 0 & 0 & 0 & -10.625 .000 & 27.767.556.000 & $-\% 0,0383$ \\
\hline Teknoloji & -53.980 .562 & 26.238.414 & $\mathbf{0}$ & $\mathbf{0}$ & $\mathbf{0}$ & $\mathbf{0}$ & -27.742 .148 & 1.861.439.117 & $-\% 1,4904$ \\
\hline NETAŞ TELEKOMÜNIKASYON A.Ş. & -53.980 .562 & 26.238 .414 & 0 & $\mathbf{0}$ & 0 & 0 & -27.742 .148 & 1.861 .439 .117 & $-\% 1,4904$ \\
\hline Ulaştırma, Haberleşme ve Depolama & -9.979 .000 & $\mathbf{0}$ & $\mathbf{0}$ & -148.846 .000 & $\mathbf{0}$ & 2.084.204.000 & 1.925.379.000 & 201.704.673.536 & $\% 0,9546$ \\
\hline PEGASUS HAVA TAŞIMACILIĞI A.Ş. & 0 & 0 & 0 & 0 & 0 & 0 & 0 & 13.664.887.536 & $\% 0,0000$ \\
\hline TURKCELL İLETIŞiM HIZZMETLERİ A.Ş. & 8.186 .000 & 0 & 0 & -148.846 .000 & 0 & 1.059 .866 .000 & 919.206 .000 & 42.765 .275 .000 & $\% 2,1494$ \\
\hline TÜRK HAVA YOLLARI A.O. & 0 & 0 & 0 & 0 & 0 & 0 & 0 & 109.076.000.000 & $\% 0,0000$ \\
\hline TÜRK TELEKOMÜNIKASYON A.Ş. & -18.165 .000 & 0 & 0 & 0 & 0 & 1.024 .338 .000 & 1.006 .173 .000 & 36.198 .511 .000 & $\% 2,7796$ \\
\hline TOPLAM & -61.375 .345 & 26.238.414 & -4.914 .000 & -148.846 .000 & -13.805 .614 & 2.084.204.000 & 1.881.501.455 & 458.122.087.602 & \%0,4107 \\
\hline
\end{tabular}


Aslında TFRS 15'e göre, bir müşteriyle sözleşme yapılması için katlanılan ek maliyetlerin geri kazanılması bekleniyorsa, bu maliyetlerin finansal tablolarda varlık olarak sunulması gerekmektedir (TFRS 15, para. 91-92). Söz konusu maliyetleri bazı firmalar peşin ödenmiş giderler hesabında raporlarken, bazı firmalar da maddi olmayan duran varlık olarak siniflandırmayı tercih etmektedir. Farklı kalemler altında raporlamanın kar veya zarar tablosuna veya finansal durum tablosundaki varlık toplamına etkisi bulunmasa da zaman içinde işletmeler tarafından daha tutarlı bir sunum yapılacağ1 ve ek maliyetlerin raporlanması ile ilgili birliktelik sağlanacağ1 düşünülmektedir (Şavlı, 2016: 64-65).

TFRS 15'e geçiş, tutar olarak önemli olmamakla beraber, çalışma kapsamındaki işletmelerin birçoğunun ticari alacaklar kalemini de etkilemiştir. Dipnotlar detaylı incelendiğinde, ticari alacaklar başlığı altında ertelenmiş finansman gelirleri kaleminin de yer aldığ 1 görülmektedir. Dolayısıyla sözleşmelerdeki finansman unsurlarının TFRS 15 hükümleri doğrultusundan ayrıştırılması ve ticari alacaklarda bir azalış olarak raporlanması nedeniyle, genel olarak ticari alacaklar kaleminde azalış olmuştur. Diğer taraftan, ticari alacaklarında artış olan işletmeler de bulunmaktadır. Bunun muhtemel nedeni de ticari alacaklar içinde raporlanan, TFRS 15 kapsamında muhasebeleştirilmiş olan sözleşme varlıklarıdır.

Dört işletmenin stoklar kaleminde de değişim olmuştur. $\mathrm{Bu}$ değişiklik muhtemelen hasılatın mal veya hizmetin müşteriye devredilerek edim yükümlülüğü yerine getirildikçe kaydedilmesinden kaynaklanmaktadır. TMS 18'e göre hasılatın muhasebeleştirilebilmesi için malların sahipliği ile ilgili önemli risk ve getirilerin alıcıya devredilmiş olması gerekirken, TFRS 15 malların kontrolünün müşterinin eline geçmiş olmasını dikkate almaktadır (KPMG, 2018). Yeni hasılat standardındaki bu yaklaşım hem hasılatın muhasebeleştirilme zamanlamasını hem de mal satışı ile ilgili olarak stoklar hesabının bakiyesini etkilemektedir. 
The Journal of Accounting and Finance- October 2021 (92): 91-114

Tablo 7. TFRS 15 'e Geçişin Yükümlülüklere ve Kar/Zarara Etkileri (TL)

\begin{tabular}{|c|c|c|c|c|c|c|c|}
\hline & $\begin{array}{l}\text { KVYK'ya } \\
\text { Etkisi }\end{array}$ & $\begin{array}{l}\text { UVYK'ya } \\
\text { Etkisi }\end{array}$ & $\begin{array}{c}\text { Yab. } \\
\text { Kaynaklara } \\
\text { Etkisi /Aktif } \\
\text { Toplamı }\end{array}$ & $\begin{array}{l}\text { Hasilata } \\
\text { Etkisi }\end{array}$ & $\begin{array}{l}\text { Brüt Kara Net } \\
\text { Etkisi }\end{array}$ & $\begin{array}{c}\text { Kar/Zarara } \\
\text { Net Etkisi }\end{array}$ & $\begin{array}{l}\text { Kar/Zarardaki } \\
\text { Değişim }\end{array}$ \\
\hline Elektrik Gaz ve Su & $\mathbf{0}$ & $\mathbf{0}$ & $\% 0,0000$ & -32.691 .000 & $\mathbf{0}$ & $\mathbf{0}$ & $\% 0,0000$ \\
\hline ENERJISA ENERJİ A.Ş. & 0 & 0 & $\% 0,0000$ & -32.691 .000 & 0 & 0 & $\% 0,0000$ \\
\hline İmalat Sanayii & 22.338 .000 & 119.340 .000 & $\% 0,1861$ & 59.941.015 & 35.686 .015 & -28.831 .048 & $-\% 0,5381$ \\
\hline ANADOLU CAM SANAYİI A.Ş. & 0 & 0 & $\% 0,0000$ & 6.525 .000 & 2.557 .000 & -1.137 .000 & $-\% 0,2501$ \\
\hline ARÇELİK A.Ş. & 22.338 .000 & 119.340 .000 & $\% 0,4994$ & -29.034 .000 & -29.034 .000 & -23.583 .000 & $-\% 2,6816$ \\
\hline $\begin{array}{l}\text { KARTONSAN KARTON SANAYİ VE TİCARET } \\
\text { A.Ş. }\end{array}$ & 0 & 0 & $\% 0,0000$ & -76.985 & -76.985 & -60.048 & $-\% 0,0529$ \\
\hline PETKIMM PETROKİMYA HOLDİNG A.Ş. & 0 & 0 & $\% 0,0000$ & 67.434 .000 & 67.434 .000 & 0 & - \\
\hline SODA SANAYIII A.Ş. & 0 & 0 & $\% 0,0000$ & 28.970 .000 & 6.501 .000 & 5.071 .000 & $\% 0,3257$ \\
\hline TOFAŞ TÜRK OTOMOBİL FABRİKASI A.Ş. & 0 & 0 & $\% 0,0000$ & -11.040 .000 & -11.040 .000 & -8.611 .000 & $-\% 0,6472$ \\
\hline TRAKYA CAM SANAYİI A.Ş. & 0 & 0 & $\% 0,0000$ & -2.837 .000 & -655.000 & -511.000 & $-\% 0,0499$ \\
\hline Mali Kuruluşlar & 22.338 .000 & 121.172.908 & $\% 0,0924$ & -114.149 .000 & -21.684 .413 & -53.083 .243 & $-\% 0,4452$ \\
\hline KOÇ HOLDİNG A.Ş. & 22.338 .000 & 122.556 .000 & $\% 0,1157$ & -32.250 .000 & -32.250 .000 & -30.037 .000 & $-\% 0,3553$ \\
\hline POLISAN HOLDINGG A.Ş. & 0 & -1.383 .092 & $-\% 0,0613$ & 0 & 29.047 .587 & -8.659 .243 & $-\% 28,5763$ \\
\hline TÜRKIYYE ŞIŞE VE CAM FABRİKALARI A.Ş. & 0 & 0 & $\% 0,0000$ & -81.899 .000 & -18.482 .000 & -14.387 .000 & $-\% 0,4185$ \\
\hline Teknoloji & 8.955 .696 & $\mathbf{0}$ & $\% 0,4811$ & 12.137.215 & -61.116 & 8.908 .026 & $\% 64,7688$ \\
\hline NETAŞ TELEKOMÜNIKASYON A.Ş. & 8.955 .696 & 0 & $\% 0,4811$ & 12.137.215 & -61.116 & 8.908.026 & $\% 64,7688$ \\
\hline Ulaştırma, Haberleşme ve Depolama & 384.672.000 & 28.711.000 & $\% 0,2049$ & -69.571 .843 & -399.018 .843 & 227.775 .002 & $\% 4,4107$ \\
\hline PEGASUS HAVA TAŞIMACILIĞI A.Ş. & 0 & 0 & $\% 0,0000$ & 24.046 .157 & 24.046 .157 & 18.756 .002 & $\% 3,8528$ \\
\hline TURKCELL İLETIŞ̧iM HİZMETLERİ A.Ş. & 19.737 .000 & 28.711 .000 & $\% 0,1133$ & -17.824 .000 & -347.271 .000 & 137.924 .000 & $\% 6,5843$ \\
\hline TÜRK HAVA YOLLARI A.O. & 75.000 .000 & 0 & $\% 0,0688$ & -46.000 .000 & -46.000 .000 & -52.000 .000 & $-\% 1,2692$ \\
\hline TÜRK TELEKOMÜNIKASYON A.Ş. & 289.935 .000 & 0 & $\% 0,8010$ & -29.794 .000 & -29.794 .000 & 123.095 .000 & $\% 8,1285$ \\
\hline TOPLAM & 438.303.696 & 269.223 .908 & $\% 0,1544$ & -144.333 .613 & -385.078 .357 & 154.768 .737 & $\% 0,6677$ \\
\hline
\end{tabular}


Tablo 7'de ise TFRS 15'e geçişin yükümlülüklere ve işletmelerin kar veya zararlarına etkileri sunulmuştur. Yeni hasılat standardına geçişin kısa ve uzun vadeli yabancı kaynaklara etkisi oldukça sınırlıken, kar veya zarardaki değişim daha belirgindir.

Kısa vadeli yabancı kaynaklardaki etkiyi bazı işletmeler bu başlık altında topluca raporlarken, bazı işletmeler kalem bazında detay vermiştir. TFRS 15'e geçişle birlikte artan ve azalan kısa vadeli yabancı kaynak kalemleri diğer kısa vadeli yükümlülükler, ticari borçlar ve ertelenmiş gelirlerdir. Diğer kısa vadeli yükümlülükler kaleminin detayı incelendiğinde, bu kalemin altında da ertelenmiş gelirlerin bulunduğu görülmektedir. En çok etkiyi yaratan kalem olan ertelenmiş gelirler, telekomünikasyon firmaları için ön ödemeli aboneler tarafından nakden ödenip satın alınan fakat henüz faydalanılmamış hizmetlere ilişkin sözleşme yükümlülüklerinden oluşmaktadır. Örneğin Türk Telekomünikasyon A.Ş.'de "ertelenmiş gelirler" kaleminde TFRS 15'e geçişle birlikte artış olmuştur. Bu artışın nedeni faturalandırılmış ancak henüz kullanılmamış dakikaların TFRS 15'e göre toplam sözleşme bedelinin bütün mal ve hizmetlere tek başına satış fiyatları temel alınarak dağıtılması ile oluşan ertelenmiş aylık sabit ücret gelirlerinden oluşmaktadır. Diğer işletmeler açısından değerlendirme yapıldığında da, bu kalemlerdeki değişimlerin bedelsiz olarak verilecek ürünler veya birden fazla mal veya hizmet içeren paket sözleşmelere ilişkin hizmet yükümlülüklerinden kaynaklanmasının muhtemel olduğu belirlenmiştir.

Etkilenen uzun vadeli yabancı kaynak kalemleri ise diğer uzun vadeli yükümlülükler, diğer uzun vadeli karşılıklar (garanti karşılıkları) ve ertelenmiş gelirlerdir. Kısa vadeli yabancı kaynaklardan farklı olarak uzun vadeli yabancı kaynaklar altında diğer uzun vadeli karşılıkların yer almasının nedeni müşteriler tarafından bir bedel ödenerek ayrıca satın alınan garantilerin varlığıdır. Özellikle Arçelik gibi dayanıklı tüketim malları satan işletmelerde TFRS 15'e geçişle birlikte karşılıklarda değişim olduğu gözlemlenmektedir.

TFRS 15'e geçişin karlılığa olan etkileri incelendiğinde, teknoloji alanında faaliyet gösteren Netaş Telekomünikasyon'da kardaki en yüksek yüzdesel artışın gerçekleştiği görülmektedir. Firmanın devam eden sözleşmelere ilişkin varlıklar ve ertelenmiş gelirler kalemlerinde de önemli ölçüde artış olmuştur. Bunun sebebi firmanın ürettiği ekipmanlarla ilgili olarak verdiği garanti hizmetleridir. İşletmenin kanuni bir zorunluluğu olmaması ve müşterilerinin garanti beklentisi de bulunmaması doğrultusunda, garanti hizmetleri ürünlerden ayrı olarak fiyatlandırılmakta ve bu nedenle de ayrı bir edim olarak değerlendirilmektedir. Bu kapsamda, daha önce garanti süresi başlamadığı ama maliyetleri oluştuğu için gelir olarak yansıtılmış tutarlar, TFRS 15 'e geçiş esnasında devam eden sözleşmelere ilişkin varlıklar ve ertelenmiş gelirler hesaplarında raporlanmıştır. Garanti hizmetlerine ilişkin tamamlanmış edimler de hasılat olarak yansitılmıştır.

Bu çalışmadaki diğer işletmelerin aksine 2018 yılı itibariyle TFRS 15'e geçişin etkilerini açıklamamış olmakla birlikte, Netaş gibi teknoloji alanında faaliyet gösteren 


\section{The Journal of Accounting and Finance- October 2021 (92): 91-114}

Aselsan Elektronik işletmesi, yeni hasılat standardını TMS 8 Muhasebe Politikaları, Muhasebe Tahminlerinde Değişiklikler ve Hatalar standardı kapsamında 1 Ocak 2015 tarihinden itibaren sunulan her geçmiş raporlama dönemi için geriye dönük olarak uyguladığını açıklamıştır. İşletme, 31 Aralık 2016 ve 31 Aralık 2017 tarihleri itibariyle TFRS 15'e geçişin geriye dönük etkilerini hem finansal durum tablosu için hem de kar veya zarar ve diğer kapsaml gelir tablosu için sunmuştur. Yeni standarda geçişle birlikte 31 Aralık 2017 tarihi itibariyle finansal durum tablosunda yer alan uzun vadeli ticari alacaklar, MODV, kısa vadeli ticari borçlar, ertelenmiş gelirler kalemlerinin arttığı, kısa vadeli ticari alacaklar ve uzun vadeli karşılıklar kalemlerinin azaldığı tespit edilmiştir. Kar veya zarar tablosunda ise hasılat ve finansman giderleri kalemlerinin arttığ1, satışların maliyeti kaleminin de azaldığı görülmüştür. Bir bütün olarak değerlendirme yapıldığında, TFRS 15'in geriye dönük uygulanmasıyla birlikte 2017 yıl sonu itibariyle Aselsan Elektronik'in dönem karının yaklaşık \%1 oranında azaldığ belirlenmiştir. TFRS 15'in şirketin finansal durum ve performansında yol açtığ değişikliklerin temel sebebi yıllara yaygın sözleşmelerin muhasebeleştirilmesi ile ilgilidir. İşlem bedellerinin önemli finansal bileşen içermesi karlılığa negatif etki yaparken, ölçüm yönteminin değişmesinden kaynaklı etkiler (zamana yaygın muhasebeleşme kriterlerine uymayan bazı edim yükümlülüklerinin zamanın belli bir anında ve çıktı yöntemi ile hasılat olarak muhasebeleştirilmesi) ise karlılığı pozitif etkilemiştir.

Polisan Holding'de ise yeni hasılat standardıyla birlikte net karın yaklaşık \%29 oranında düştügü görülmektedir. Bunun sebebinin de büyük ölçüde özkaynak yöntemiyle değerlenen yatırımların karlarından paylar kaleminden kaynaklandığı belirlenmiştir. Hem finansal durum tablosunda yer alan ilgili yatırım kalemindeki düşüş, hem de kar ve zarar tablosundaki özkaynak yöntemiyle değerlenen yatırımların karlarından/zararlarından paylar kalemindeki düşüş dikkate alındığında, TFRS 15'in Polisan Holding' in sahip olduğu bir iştirak ve/veya bir iş ortaklığının karlılığı üzerinde negatif etki yaptığı değerlendirilebilmektedir. Özkaynak yönteminde, iştiraklerin ve iş ortaklıklarının satın alma sonrasındaki kar veya zararları, yatırımcı işletmenin iştirakteki ve iş ortaklığındaki payı ölçüsünde net dönem karına/zararına ve yatırımın defter değerine yansıtıldığından, iştirak veya iş ortaklığının kar/zararındaki değişimler, yatırımcı işletmeyi de direkt olarak etkilemektedir.

Haberleşme sektöründe yer alan Turkcell İletişim Hizmetleri ve Türk Telekomünikasyon firmalarının net karlarında \%6-\%8 civarında artış olduğu görülmektedir. TMS $18^{\prime} \mathrm{e}$ göre TFRS $15^{\prime}$ de hasılatın daha gecikmeli olarak muhasebeleştirildiğini açıklayan Türk Telekomünikasyon işletmesinde TFRS 15'e geçişle birlikte hasılat azalmasına ve finansman giderleri artmasına rağmen, pazarlama, satış ve dağıtım giderlerindeki daha yüksek azalış, işletmenin raporladığı net zararın azalmasına yol açmıştır. TFRS 15'e geçişle birlikte Turkcell İletişim Hizmetleri'nin de hasılatında ve pazarlama giderlerinde düşüş görülürken, Türk Telekom'dan farklı olarak satışların maliyeti kaleminde de bir artış olduğu göze çarpmaktadır. Ancak pazarlama giderlerindeki azalışın daha yüksek olması nedeniyle, yeni hasılat standardı Turkcell'in de karlılığında olumlu etki yapmıştır. Pazarlama giderlerindeki azalışın sebebi, daha önce de açıklandığı üzere TMS 18 kapsamında oluştukları yıl kar veya zararda 
muhasebeleştirilen abone kazanma/edinme ve tutma maliyetlerinin belirli koşulların sağlanması durumunda aktifleştiriliyor olmalarıdır. Satışların maliyeti kalemindeki artışın sebebi de aktifleştirilmiş olan abone kazanım maliyetlerine ilişkin itfa paylarının bu kaleme yansitilmasidır.

İmalat sanayinde faaliyet gösteren işletmeler arasında yeni standarda geçişle birlikte karlılığında en yüksek değişim olan işletme Arçelik'tir. TMS 18'de satış sözleşmelerinde müşteriye verilen garantiler konusunda özel bir düzenleme olmamas1, standart garantili satışlar dışında normal garanti süresini uzatan ilave garanti satışlarının yaygınlaşmasıyla birlikte farklı uygulamaların ortaya çıkmasına neden olmuştur. Ancak TFRS 15'de normal satış sözleşmesi kapsamındaki garantilere ilave olarak satılan uzatılmış garantiler ayrıştırılmış ve ayrı bir yükümlülük olarak tanımlanarak, ilgili dönemlerde hasılat olarak yansitılmaya başlanmıştır (Şavlı,2018:99). TFRS 15’e geçişten kaynaklanan, uzatılmış garanti satışlarının düzeltme etkisi, Arçelik’in dönem net karında \%2,68'lik bir azalış yaratmıştır.

TFRS 15'e geçiş, Pegasus işletmesinin yalnızca hasılat kaleminde artış yaratmış, işletmenin başka hiçbir finansal durum tablosu ve kar veya zarar tablosu kaleminde değişim olmamıştır. Hasılattaki artış nedeniyle dönem net karında \%3,85 oranında artış olan Pegasus'taki bu etkinin sebebi yolcu hizmet ücretleridir. Yolcu hizmet ücretleri, bilet fiyatı üzerine eklenen ve satış hizmetini gerçekleştirme karşılığında yolculardan alınan bir bedeldir. TFRS 15 'e geçiş öncesinde söz konusu yolcu hizmet ücretleri bilet satıldığı anda hasılat olarak muhasebeleştirilirken, yeni hasılat standardı hükümlerine göre taşıma hizmetine bağlı bir edim yükümlülüğü olarak değerlendirilmiş ve yolcu taşıma hizmetinin gerçekleştirilmesiyle beraber hasılat olarak kaydedilmeye başlanmıştır. Dolayısıyla Pegasus'un karlılığındaki artışın temel sebebi yolcu hizmet ücretlerinin hasılat olarak muhasebeleştirilmesindeki zamanlama farklılığıdır.

Pegasus'la aynı sektörde faaliyet gösteren Türk Hava Yolları'nda ise tam tersi olarak yaklaşık \%1,27'lik bir kar azalışı söz konusudur. Kardaki azalışın nedeni TFRS 15 'le birlikte bilet yanma ve bilet değişiklik gelirlerinde azalış olmasıdır. TFRS 15 öncesinde geçmiş istatistiki veriler kullanılarak beklenen yanma miktarı tahmin edilirken, yeni hasılat standardıyla birlikte uçuş tarihi itibariyle uçulmamış biletler üzerinden bilet yanma geliri muhasebeleştirilmektedir. Bilet değişiklik gelirleri ile ilgili olarak da daha önce yolcu ücretini ödeyerek değişiklik talep ettiği tarihte gelir kaydedilirken, TFRS 15 'in yürürlüğe girmesiyle birlikte değişiklik hizmeti yolculuktan ayrı değerlendirilmemeye başlanmış ve yolcunun uçmadiğ 1 durumda bu değişiklik hizmetinden faydalanamayacağ beraber uçuş tarihinde gelir olarak yansıtılmaya başlanmıştır. Söz konusu değişiklikler, Türk Hava Yolları'nın yükümlülüklerinde artışa, gelirlerinde ve karlılığında azalışa neden olmuştur.

TFRS 15'e geçişin finansal etkilerinin daha net ortaya koyulabilmesi bakımından, bir gruptaki ortalamanın (TFRS 15 öncesi rakamlar) diğer gruptaki ortalamadan (TFRS 15 sonrası rakamlar) önemli derecede farklı olup olmadığının 
The Journal of Accounting and Finance- October 2021 (92): 91-114

belirlenebilmesi için ilişkili (bağımlı) örnekler t testi yapılmış (İslamoğlu, 2009: 206) ve çalışmada yer alan 16 işletmenin verileri dahil edilmiştir.

Tablo 8. TFRS 15 Uygulaması ile Bazı Finansal Kalemlerde Meydana Gelen Değișimlerin Anlamlılık Düzeyleri

\begin{tabular}{|l|c|}
\hline & İki Yönlü Anlamlılık Düzeyi \\
\hline Ticari Alacaklar & 0,553 \\
\hline Stoklar & 0,940 \\
\hline MODV & 0,164 \\
\hline KVYK & 0,142 \\
\hline UVYK & 0,124 \\
\hline Hasılat & 0,314 \\
\hline Satışların Maliyeti & 0,496 \\
\hline Brüt Kar & 0,304 \\
\hline Kar/Zarar & 0,452 \\
\hline
\end{tabular}

Dokuz finansal tablo kaleminin her biri için bağımlı örnekler t testi \%95 güven aralığında yapılmış olup, hesaplanan iki yönlü anlamlılık düzeyleri Tablo 7'de sunulmuştur. İki yönlü anlamlılık düzeylerinin hepsinin 0,05 'ten büyük olduğu dikkate alındığında, çalışmaya dahil edilen işletmeler için TFRS 15'e geçişle birlikte, hasılat ve net kar/zararın da dahil olduğu yukarıda yer alan finansal tablo kalemlerinde anlamlı farklılıklar ortaya çıkmadığ ifade edilebilmektedir.

Ayrıca, on iki finansal tablo kaleminin her biri için imalat sanayii, mali kuruluşlar ve ulaştırma, haberleşme ve depolama sektörlerinde faaliyet gösteren 14 işletme için bağımlı örnekler t testi \%95 güven aralığında yapılmış olup, hesaplanan iki yönlü anlamlılık düzeyleri Tablo 9'da sunulmuştur.

Tablo 9. TFRS 15 Uygulaması ile Bazı Finansal Kalemlerde Meydana Gelen Değișimlerle İlgili Sektör Bazında İki Yönlü Anlamlılık Düzeyleri ${ }^{2}$

\begin{tabular}{|l|c|c|c|}
\hline & $\begin{array}{c}\text { Imalat } \\
\text { Sanayii }\end{array}$ & $\begin{array}{c}\text { Mali } \\
\text { Kuruluşlar }\end{array}$ & $\begin{array}{c}\text { Ulaştırma, } \\
\text { Haberleşme ve } \\
\text { Depolama }\end{array}$ \\
\hline Ticari Alacaklar & 0,367 & 0,357 & 0,685 \\
\hline Devam Eden Sözleşmelere İlişkin Varlıklar & - & - & - \\
\hline Stoklar & 0,374 & 0,423 & - \\
\hline Peşin Ödenmiş Giderler & - & - & 0,391 \\
\hline Özkaynak Yöntemiyle Değerlenen Yatırımlar & - & 0,279 & - \\
\hline MODV & - & - & 0,182 \\
\hline KVYK & 0,200 & 0,423 & 0,244 \\
\hline UVYK & 0,356 & 0,429 & 0,391 \\
\hline Hasılat & 0,497 & 0,251 & 0,329 \\
\hline
\end{tabular}

2 Elektrik, gaz ve su ile teknoloji sektörlerinde yalnızca birer firma bulunduğundan, hesaplama yapılamamıştır. 
Muhasebe ve Finansman Dergisi - Ekim 2021

(92): 91-114

\begin{tabular}{|l|l|l|l|}
\hline Satışların Maliyeti & 0,326 & 0,235 & 0,391 \\
\hline Brüt Kar & 0,265 & 0,823 & 0,363 \\
\hline Net Kar/Zarar & 0,294 & 0,109 & 0,295 \\
\hline
\end{tabular}

Seçilmiş finansal tablo kalemleri ile ilgili olarak yapılmış olan ilişkili (bağımlı) örnekler t testi, hesaplanan iki yönlü anlamlılık düzeylerine göre de TFRS 15 öncesi ve sonrası rakamları arasında hiçbir sektör için anlamlı bir farklılık olmadığını göstermektedir.

\section{SONUÇ}

1 Ocak 2018 tarihinden sonra başlayan hesap dönemlerinde uygulanmak üzere yürürlüğe giren UFRS 15 Müşteri Sözleşmelerinden Hasılat standardı ile hasılatın tutarı, zamanlaması ve hasılatla ilgili yapılması gereken dipnot açıklamaları bakımından finansal tabloların daha kaliteli ve karşılaştırılabilir hale getirilmesi amaçlanmıştır. UMS 11 ve UMS 18'deki rehberliğin yeterli olmaması sonucunda ortaya çıkan farklı muhasebeleştirme uygulamaları, hem UFRS 15'de yer alan beş adım modeli ile tek ve kapsamlı bir çerçevede birleştirilmiş, hem de hasılatla ilgili olarak UFRS ile Amerikan GKGMİ arasındaki yakınsama süreci tamamlanmıştır (IFRS Foundation, 2021).

Bu çalışmada 2018 yılı itibariyle yürürlüğe girmiş olan TFRS 15'e geçişin BİST 100 endeksinde işlem gören firmalar üzerindeki finansal etkilerinin tespit edilmesi amacıyla işletmelerin 2018 yılsonu finansal tabloları ve dipnotları kullanılarak içerik analizi yapılmıştır. BİST 100 endeksinde yer alan işletmelerden yeni standardın finansal tablolarda önemli etki yarattığını açıklayan 17 firmadan, TFRS 15 ve TFRS 9 etkilerini tek kalemde açıklayan bir firma dışındaki 16 firma çalışmaya dahil edilmiştir.

TFRS 15'in uygulanmasıyla birlikte varlık kalemlerinde meydana gelen değişimler dikkate alındığında, en çok etkilenen sektörlerin teknoloji ile ulaştırma, haberleşme ve depolama sektörleri olduğu belirlenmiştir. Genel olarak yeni hasılat standardına geçişin varlık kalemlerinde yarattı̆̆ 1 değişimlerin bir müşteriyle sözleşme yapılması için katlanılan ek maliyetlerin (abone kazanma/edinme ve tutma maliyetleri, satış komisyonları, vb.) muhasebeleştirilmesi, sözleşmelerdeki finansman unsurlarının ayrıştırılması, sözleşme varlıklarının ve stokların raporlanmasıyla ilgili hususlarından kaynaklandığı görülmüştür.

Yeni hasılat standardının yabancı kaynaklar üzerindeki etkilerinin varlıklara kıyasla daha düşük olduğu belirlenmiştir. Yabancı kaynaklar üzerindeki etkiler genel olarak nakden ödemesi yapılmış ancak henüz faydalanılmamış olan hizmetlere ilişkin sözleşme yükümlülükler ve satın alınan ürünlerin fiyatına dahil olmayan, ayrıca bir bedel ödenerek satın alınan garantilerin muhasebeleştirilmesiyle ilgilidir.

Karlılık açısından değerlendirme yapıldığında da en yüksek artışın teknoloji ile ulaştırma, haberleşme ve depolama sektörlerinde gerçekleştiği, en yüksek kar azalışının da bir mali kuruluş olan Polisan Holding'de özkaynak yöntemiyle değerlenen yatırımları nedeniyle oluştuğu tespit edilmiştir. Ayrıca Arçelik ve Türk Hava 


\section{The Journal of Accounting and Finance- October 2021 (92): 91-114}

Yolları'nda da diğer işletmelerden daha fazla kar düşüşü olduğu belirlenmiştir. Karlılıktaki değişimler özetle uzatılmış garantili satışlar, müşteriyle sözleşme yapılması için katlanılan ek maliyetlerin aktifleştirilmesi ve daha sonra zamana yayılı olarak itfa edilmesi, yolcu hizmet ücretleri, bilet yanma ve bilet değişiklik gelirlerinin muhasebeleştirilmesindeki farklılıklardan kaynaklanmaktadır.

Bu çalışmanın sonuçları Cooper'ın (2010) tespitleriyle uyumludur. TMS 18'in telekomünikasyon işletmelerinde kullanımında, hasılatın "yapay” olarak ertelenmesi ve benzer işlemler için hasılatın farklı şekillerde muhasebeleştirilmesi söz konusuydu (Cooper, 2010: 4). TFRS 15'e geçişle birlikte telekomünikasyon sektöründe karlılığın artması, birden fazla mal veya hizmet içeren paket sözleşmelere ilişkin hasılatın artık ertelenmeden muhasebeleştirilmesinden kaynaklanmaktadır.

TFRS 15 öncesi ve sonrası rakamları kullanılarak ilişkili (bağımlı) örnekler t

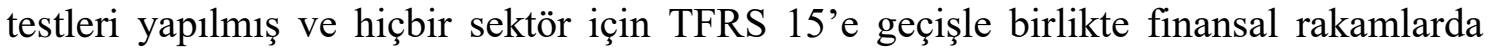
istatistiksel olarak anlamlı bir değişiklik tespit edilememiştir. Dolayısıyla, sektörel olarak varlıklar, borçlar ve karlılıkta farklı yüzdesel değişimler gerçekleşmiş olmakla birlikte, beklentilerin aksine TFRS 15'e geçiş, finansal tablo kelimelerinde anlamlı bir değişim de yaratmamıştır. Bu çalışmanın bulguları, STOXX Europe 50 endeksindeki 48 firmanın 2018 yılı raporları kullanılarak yapılan değerlendirme ile birkaç sektör (özellikle telekomünikasyon) dışında UFRS $15^{\prime}$ 'e geçişin Avrupa'nın en büyük işletmelerinin çoğunun finansal rakamlarına etkisinin oldukça az olduğunun belirlendiği Napier ve Stadler (2020) çalışması ile büyük ölçüde uyumludur. Ayrıca Vaicekauskas'un (2020) Litvanya'daki halka açık işletmelerin finansal tablo ve dipnotlarına yaptığ içerik analiziyle elde ettiği, UFRS 15'in ilk kez uygulanmasının Litvanya borsasında işlem gören şirketlerin finansal tabloları üzerinde önemli bir etkisi olmadığı sonucu da bu çalışma ile tamamen uyumludur.

Benzer şekilde BİST'teki işletmelerin yeni hasılat standardının önemli bir değişikliğe neden olmadığı konusunda açıklamaları olduğunu belirleyen Özerhan ve Sultanoğlu (2019) çalışması ve BİST 50'de listelenen işletmelerin TFRS 15'e geçişle ilgili yaptıkları açıklamalarla ilgili Ünlütürk, Deveci ve Dağlı'nın (2019) bulguları da bu çalışmanın sonuçlarını destekler niteliktedir.

Özellikle belirli konularda TMS 18'deki yetersiz yönlendirme sonucunda, aynı sektörde faaliyet gösteren işletmelerin bile benzer işlemler için farklı muhasebeleştirme yöntemleri kullanmaları, açıklanan finansal bilgilerin karşılaştırılabilirliğini ve anlaşılabilirliğini olumsuz etkilemektedir. TFRS $15^{\prime}$ in uygulanmaya başlanmasıyla birlikte her ne kadar raporlanan finansal rakamlarda önemli bir değişiklik olmadığı tespit edilmişse de, yeni hasılat standardı sayesinde hasılatın doğru zamanda muhasebeleştirilmesi ve işletmelerin uzatılmış garantiler, yolcu hizmet ücreti, bilet değişiklik ve yanma ücretleri, değişken işlem fiyatı yaratan hacim indirimleri gibi birçok işlemde paralel muhasebe uygulamaları gerçekleştirmelerinin sağlanması bakımından önemli bir adım atılmıştır. 
Aslında genel olarak değerlendirildiğinde, UFRS 15'in karlılık veya net varlıklar üzerindeki etkisi çok yaygın veya belirgin değildir, ancak işletmelerin müşterileriyle yaptıkları birçok farklı türde sözleşmeyi tam olarak anlamak ve standardı uygulamak için gösterdikleri çaba son derece değerli ve önemlidir. UFRS 15'in daha fazla açıklık ve tutarlılık ve daha iyi dipnot açıklamaları gibi raporlama açısından sağladığı faydalar, muhtemelen standardın daha fazla benimsenmesi ve uygulanmasıyla birlikte ilerleyen dönemlerde ortaya çıkacaktır (Martin, 2018).

Bu çalışmanın en önemli kısıtı, içerik analizinin yalnızca BİST 100'de listelenen işletmeler üzerinde gerçekleştirilmiş olmasıdır. Gelecek çalışmalarda, UFRS 15'e geçişin finansal etkilerinin değerlendirilmesi amacıyla farklı ülke borsalarında işlem gören daha fazla sayıda işletme ile karşılaştırmalı bir analiz yapılabilir ve UFRS 15 kapsamında yapılması gereken dipnot açıklamalarının kalitesinde zaman içinde bir değişiklik olup olmadığı ve dipnot açıklamalarının kalitesini etkileyen faktörlerin tespiti konularında çalışılabilir.

\section{KAYNAKLAR}

Aktaş, Rabia - Varol, İsmail Deniz (2017), “Yeni Hasılat Standardı UFRS 15'e Göre Hasılatın Muhasebeleştirilmesi: Çok Unsurlu Sözleşmeler Ve Sözleşme Değişiklikleri”, Muhasebe ve Finansman Dergisi, 73, ss.27-50.

Aladwan, Mohammad (2019), "Fluctuations of Stock Price and Revenue after the Early Adoption of IFRS 15, "Revenue from Contracts with Customers” ”, Italian Journal of Pure and Applied Mathematics, 41, pp.724-736.

Altaji, Fatema Sami - Alokdeh, Saleh Khalil (2019), “The Impact of the Implementation of International Financial Reporting Standards no.15 on Improving the Quality of Accounting Information”, Management Science Letters, 9, pp.2369-2382.

Beattie, Vivien (2005), "Moving the Financial Accounting Research Front Forward: The UK Contribution”, The British Accounting Review, 37(1), pp.85-114.

Boujelben, Saoussen - Kobbi-Fakhfakh, Sameh (2020), “Compliance with IFRS 15 Mandatory Disclosures: An Exploratory Study in Telecom and Construction Sectors”, Journal of Financial Reporting and Accounting, 18(4), pp.707-728.

Calayoğlu, İlker - Y1lmaz, Recep (2016), “TFRS-15'e Göre Yazılım Sektöründeki Sözleşmelerin Hasılatının Hesaplanması ve Tanınması”, PESA International Journal of Social Studies, 2(2), ss.18-42.

Chang, Allan (2018), “Analysis on Corporate Governance Compliance Standards in New Zealand - A Qualitative Study on Disclosures Using Content Analysis and Interviews”, Journal of Financial Regulation and Compliance, 26(4), pp.505525. 


\section{The Journal of Accounting and Finance- October 2021 (92): 91-114}

Ciesielski, J. T. ve Weirich, T. R. (2015), "Revenue Recognition: How It Will Impact Three Key Sectors”, Journal of Corporate Accounting \& Finance, 26(3), pp.3139.

Collings, Steven (2011), IFRS Revenue Recognition Plans Explained, https://www.accountingweb.co.uk/business/financial-reporting/ifrs-revenuerecognition-plans-explained (19.02.2021).

Cooper, Stephen (2010), Investor Perspectives: Revenue Recognition, Stephen Cooper: Revenue Recognition and Your Mobile Phone, https://www.ifrs.org/content/dam/ifrs/resources-for/investors/investorperspectives/investor-perspective-rr-jun-2010.pdf (29.07.2021).

Çalış, Yıldırım Ercan (2019), "Hasılatın TFRS 15 Müşteri Sözleşmelerinden Hasılat Standardı, BOBİ FRS Bölüm 5 ve Vergi Kanunlarına Göre Karş1laştırmalı İncelenmesi”, İstanbul Aydın Üniversitesi Dergisi, 11(4), ss.355-377.

Davern, Michael - Gyles, Nikole - Potter, Brad - Yang, Victor (2019), "Implementing AASB 15 Revenue from Contracts with Customers: The Preparer Perspective”, Accounting Research Journal, 32(1), pp.50-67.

Deloitte, “Industry Insights for IFRS", https://www2.deloitte.com/ca/en/pages/audit/articles/IFRS15.html (28.04.2021).

Epstein, Barry J. - Jermakowicz, Eva K. (2008), WILEY IFRS 2008: Interpretation and Application of International Financial Reporting Standards, John Wiley \& Sons, New Jersey.

Ergüden, A. Engin (2020), “Analysis of Tourism Companies Listed in Istanbul Stock Exchange According to IFRS-15 Standart”, International Journal of Finance \& Banking Studies, 9(1), pp.47-57.

Grant Thornton (2017), "UFRS 15 "Müşterilerle Yapılan Sözleşmelerden Doğan Hasılat" Standardı'nın Getirdikleri”, https://www.grantthornton.com.tr/enguncel/makaleler/ufrs-15-muterilerle-yaplan-sozlemelerden-doan-haslatstandardnn-getirdikleri/ (16.04.2021).

Gündüz, Gülşah Aytuğ - Yanık, Serap Sebahat (2020), "Yıllara Yaygın İnşaat Taahhüt İşleri Üstlenen İşletmelerin Finansal Tablolarının TFRS 15 - Müşteri Sözleşmelerinden Hasılat Standardı Çerçevesinde İncelenmesi ve Bir Örnek Uygulama”, Uygulamalı Ekonomi ve Sosyal Bilimler Dergisi, 2(1), ss.1-22.

IFRS 15 Revenue From Contracts With Customers, Project Summary and Feedback Statement, May 2014, https://www.ifrs.org/-/media/project/revenue-fromcontracts-with-customers/project-summary-feedback-statement.pdf (26.01.2021). 
IFRS Foundation, IFRS 15 and Research Opportunities, https://cdn.ifrs.org/content/dam/ifrs/news/2021/ifrs-15-and-researchopportunities.pdf?la=en (12.04.2021).

İslamoğlu, Ahmet Hamdi (2009), Sosyal Bilimlerde Araştırma Yöntemleri - SPSS Uygulamal1, 1. Basım, Beta Basım Yayım, İstanbul.

KAP - Finansal Tablolar, https://www.kap.org.tr/ (18.11.2020).

Keskin, Ayşe İrem - Dinçer, Banu (2015), “UFRS 15 - Müşteri Sözleşmelerinden Elde Edilen Hasılat Standardının İncelenmesi ve Telekomünikasyon Sektörüne İlişkin Bir Uygulama” Maliye Finans Yazıları, 103, ss.219-246.

Kohler, Herve - Pochet, Christine - Le Manh, Anne (2021), “Auditors as Intermediaries in the Endogenization of an Accounting Standard: The Case of IFRS 15 within the Telecom Industry” Accounting, Organizations and Society, 91, 101227, pp.1-18.

Köse, Tunç - Şengül Çelikay, Duygu (2015), "Yeni Hasılat Standardı ve Getirdiği Değişiklikler”, Mali Çözüm Dergisi, 25(127), ss.19-44.

KPMG (2018), “New Revenue Standard AASB 15: Impact on Inventory Recognition”, https://home.kpmg/au/en/home/insights/2018/11/aasb-15-revenue-standardimpact-on-inventory-recognition.html (15.08.2021).

Mahutova, Silvia, "IFRS 15 Examples: How IFRS 15 Affects Your Company", https://www.cpdbox.com/ifrs-15-examples/ (28.01.2021).

Martin, Richard, “One Year on, What Impact Has IFRS15 Had on Companies?”, https://www.accaglobal.com/in/en/member/member/accountingbusiness/2018/11/insights/ifrs15-companies.html (19.02.2021).

Mattei, Giorgia - Paoloni, Niccolo (2019), "Understanding the Potential Impact of IFRS 15 on the Telecommunication Listed Companies, by the Disclosures' Study”, International Journal of Business and Management, 14(1), pp.169-179.

McConnell, Patricia (2014), Investor Perspectives: IFRS 15 Revenue from Contracts with Customers, Revenue Recognition: Finally, a Standard Approach for All, https://www.ifrs.org/content/dam/ifrs/resources-for/investors/investorperspectives/investor-perspective-jun-2014-1.pdf (31.07.2021).

Memiş, Mehmet Ünsal (2019), "Hasılatların Muhasebeleştirilmesinde MSUGTTMS/TFRS-BOBİ FRS Karşılaştırması”, KAÜIIIBFD, 10(19), ss.236-249.

Mert, Hüseyin - Baş, Ece (2017), “TMS 18 "Hasılat” ve UFRS 15 "Müşteri Sözleşmelerinden Hasılat" Standardlarının Faktoring İşletmeleri Açısından Değerlendirilmesi”, Muhasebe ve Denetime Bakış, 52, ss.35-56. 


\section{The Journal of Accounting and Finance- October 2021 (92): 91-114}

Mirza, Abbas Ali - Holt, Graham J. (2011), Practical Implementation Guide and Workbook for IFRS, Third Edition, John Wiley \& Sons, New Jersey.

Napier, Christopher J. - Stadler, Christian (2020), "The Real Effects of a New Accounting Standard: The Case of IFRS 15 Revenue from Contracts with Customers”, Accounting and Business Research, 50(5), pp.474-503.

Özerhan, Yıldız - Sultanoğlu, Banu (2019), “Lisans Sözleşmelerinden Doğan Hasılatın TFRS 15 Kapsamında Muhasebeleştirilmesi: Yazılım Sektöründe Bir Araştırma", Muhasebe ve Finansman Dergisi, Ağustos 2019 Özel Sayı, ss.15-32.

PWC (2015), “New IFRS 15 : How Will the New IFRS 15 Standard Affect Your Company?”, $\quad$ https://www.pwc.com/sk/en/publikacie/assets/ifrs15-leafletfinal.pdf (31.07.2021).

Quagli, Alberto - Roncagliolo, Elisa - D’Alauro, Gabriele (2021), “The Preparedness to Adopt New Accounting Standards: A Study of European Companies on the Pre-Adoption Phase of IFRS 15”, International Journal of Disclosure and Governance, pp.1-14.

Rutledge, Robert W. - Karim, Khondkar E. - Kim, Taewoo (2016), “The FASB's and IASB's New Revenue Recognition Standard: What Will Be the Effects on Earnings Quality, Deferred Taxes, Management Compensation, and on IndustrySpecific Reporting?”, The Journal of Corporate Accounting \& Finance, 27(6), pp.43-48.

Şavlı, Tuba (2016), TFRS 15 Kapsamında Açıklama ve Örneklerle Hasılatın Raporlanmas1, İSMMMO Yayınlar1, İstanbul, http://archive.ismmmo.org.tr/Yayinlar/E_Kitap/HASILATIN_Raporlanmasi.pdf (03.03.2021).

TFRS 15 Müşteri Sözleşmelerinden Hasılat Standard1, https://www.kgk.gov.tr/Portalv2Uploads/files/Duyurular/v2/TFRS/TFRS_2020/ TFRS\%2015.pdf (17.02.2021).

Ünlütürk, Alim Çağdaş - Deveci, Ece Nur - Dağlı, Muhammet Fatih (2019), “ “TFRS 15 Müşteri Sözleşmelerinden Hasılat” Çerçevesinde Hasılatın Ölçülmesi ve Raporlanması", Muhasebe ve Denetime Bakış, 57, ss.247-268.

Vaicekauskas, Darius (2020), "First Time Adoption of IFRS 15 "Revenue From Contracts with Customers": The Case of Lithuanian Listed Companies”, Buhalterinès Apskaitos Teorija ir Praktika, 21, p.2. 